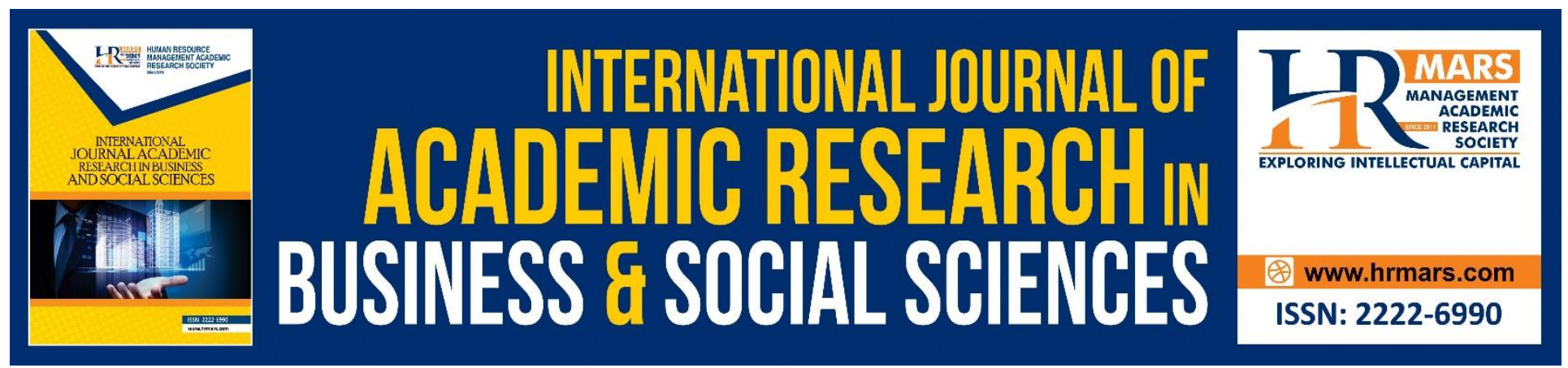

\title{
Impact of Fiscal Policy on Agricultural Output in Nigeria
}

\section{Oladipo Abimbola Oluwaseun, Oyefabi llemobola Solomon, Mary Abdul Yusuf}

To Link this Article: http://dx.doi.org/10.6007/IJARBSS/v10-i8/7528

DOI:10.6007/IJARBSS/v10-i8/7528

Received: 28 May 2020, Revised: 24 June 2020, Accepted: 27 July 2020

Published Online: 25 August 2020

In-Text Citation: (Oluwaseun et al., 2020)

To Cite this Article: Oluwaseun, O. A., Solomon, O. I., \& Yusuf, M. A. (2020). Impact of Fiscal Policy on Agricultural Output in Nigeria. International Journal of Academic Research in Business and Social Sciences, 10(8), 224243.

Copyright: @ 2020 The Author(s)

Published by Human Resource Management Academic Research Society (www.hrmars.com)

This article is published under the Creative Commons Attribution (CC BY 4.0) license. Anyone may reproduce, distribute, translate and create derivative works of this article (for both commercial and non-commercial purposes), subject to full attribution to the original publication and authors. The full terms of this license may be seen

at: http://creativecommons.org/licences/by/4.0/legalcode

\section{Vol. 10, No. 8, 2020, Pg. 224 - 243}

http://hrmars.com/index.php/pages/detail/IJARBSS

JOURNAL HOMEPAGE

Full Terms \& Conditions of access and use can be found at http://hrmars.com/index.php/pages/detail/publication-ethics 


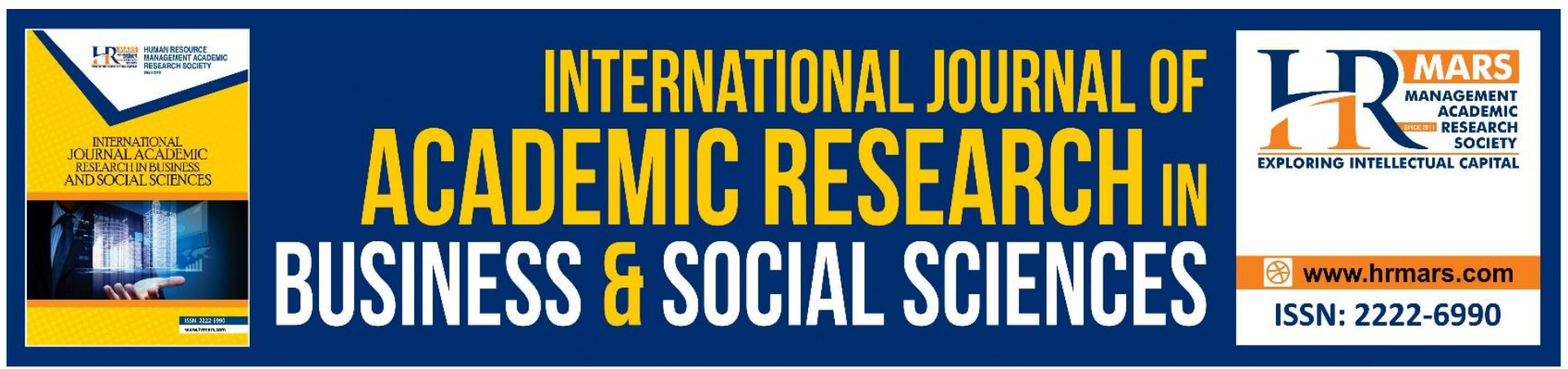

\title{
Impact of Fiscal Policy on Agricultural Output in Nigeria
}

\author{
Oladipo Abimbola Oluwaseun, Oyefabi llemobola Solomon, Mary \\ Abdul Yusuf \\ Nigerian Defence Academy, Kaduna. Nigeria \\ Email: Oladipoabimbola87@gmail.com, is.oyefabi@gmail.com,maryabdulyusuf@gmail.com
}

\begin{abstract}
This study analyses the impact of fiscal policy on agricultural output in Nigeria from 1980-2017. Data for the study were obtained from the Central Bank of Nigeria Statistical Bulletin. In order to achieve the objective of the study, Augmented Dickey-Fuller Unit Root, Johansen co-integration and Vector Error Correction Model were employed. The unit root test conducted shows that the variables were integrated of order one i.e I(1), which means that the variables are stationarity at first difference. The co-integration results showed that long-run equilibrium relationship exists among the variables. Result of the regression shows that government capital expenditure on agriculture has a positive and significant impact on agricultural output, while Government recurrent expenditure on agriculture also has a positive impact on agricultural output in Nigeria. Furthermore, the study also reveals that personal income tax has a negative and insignificant impact on agricultural output. Also, findings from the Variance Decomposition reveal that the predominant sources of variation in all the variables can be attributed to its own shock. The study therefore recommends that government should increase capital budgetary allocation to this sector in a consistent manner because of its importance to the development of the sector and to the national economy. The study further suggests that expansionary fiscal policy measures should be encouraged by the government because it will play a vital role in the growth of agriculture in Nigeria. If this measure is put in place, agriculturalists would be able to have more income to invest in agriculture. Even in the part of the government, when more money is allocated and effectively implemented in agriculture, there would be increase in agricultural output and this would increase the nation's gross domestic product (GDP).
\end{abstract}

Keyword: Fiscal Policy, Agricultural Output, Vector Error Correction Model, Nigeria, Taxation.

\section{Introduction}

The proven path to economic prosperity is agriculture. There is no region of the world that has developed a modern economy without first establishing a foundation in agriculture successfully. Even as it is now, there is no economy that can do without consuming one agricultural produce or the other. Agriculture has been and will continue to be the mainstay of most economies. 
INTERNATIONAL JOURNAL OF ACADEMIC RESEARCH IN BUSINESS AND SOCIAL SCIENCES Vol. 10, No. 8, 2020, E-ISSN: 2222-6990 @ 2020 HRMARS

In some developed countries like USA, Japan, UK, development in the agricultural sector has helped their industrialization process by providing the raw materials needed for production to a greater extent. In India, it was recorded that 28 percent of their national income comes from agriculture while about 70 percent of people in the country are engaged in agriculture where they earn income for survival. However, in Africa, agriculture creates most jobs for both the people practicing subsistence and commercial farming. Aside from the northern and southern African countries, in some oil producing countries like Nigeria, Cameroon, Cote d'Ivoire, agriculture accounts for half or more of the working population and also contributes to Gross Domestic Products (World Development Report, 2008).

Since 1980 to 2017 there has been continuous increase in capital expenditure over recurrent expenditure. Data sourced from the CBN statistical bulletin 2017 shows that in 1984, government capital spending on agriculture was 25 million naira while that of recurrent expenditure was 2 million naira. Also, in 1994, which was ten years after, capital spending was 2.8 billion naira while recurrent expenditure was 1.2 billion naira. Furthermore, in 2017, capital expenditure on agriculture was 75 billion naira and that of recurrent was 68 billion naira. From these figures, it is evident that government channels more money to capital expenditure on agriculture than recurrent expenditure on agriculture. However, there are a lots of problems still facing the sector despite all the funds budgeted for the development of the sector. These problems are inadequate social and infrastructural facilities such as good roads, proximity to the market, electricity, storage facilities and so on. In spite of these, fiscal policy is viewed as an important policy instrument that can be used to develop agricultural sector based on its roles. It is against this backdrop that this study tries to investigate the impact of fiscal policy instruments on agricultural output in Nigeria.

When it comes to the nation's development, agriculture is the main engine that stimulates economic processes because there is nothing in agricultural produce that is wasted (National Bureau of Statistics (NBS), 2016). Most of the produces are used as raw materials which are transformed into finished goods. A nation that invests in agriculture helps the industrial and other sectors of the economy to grow because of easy and cheaper access to raw materials. This brings about prosperity and development to an economy. Apart from raw materials for the manufacturing sectors, agriculture also plays some important roles which aid development. These roles include, sources of food for the growing population, foreign exchange earnings, source of income and savings for farmers, to mention but a few (Chandrasekaran, Annadurai \& Somasundaram, 2010).

In Nigeria, various policies have been formulated in order to realize these aforementioned roles. The policies also aim at strengthening agricultural sector. Some of these policies include, Operation Feed the Nation (OFN) in 1976, Green Revolution of 1980, Structural Adjustment Programme (SAP) in 1986, the Directorate of Foods, Roads and Rural Infrastructure (DFRRI) in 1987, Better Life for Rural Women also in 1987, Rural Agro-Industrial Development Scheme (RAIDS) in 2001, National Economic Empowerment Development Strategy (NEEDS, SEEDS and LEEDS) of 2003, Land Use Decree of 1976 among others. Although, these policies are important and laudable, they have not helped much in improving the agricultural sector significantly as it ought to be. The costs involved in executing these policies usually exceed the benefits ought to be derived. This might be because funds are not being channelled to real farmers or might be that the funds are diverted for other purposes.

During 1960s and early 1970s in Nigeria, agricultural section was the most important based on its contributions to economic growth and development. This situation persisted for decades before oil 
sector took over in 1970s which caused a drastic decline in the agricultural's contributions to the development in the economy (Farm Management Association of Nigeria (FAMAN), 2011). The trend in the share of agriculture from early 1960 s to date shows a huge variation and long-term decline. In 1960, it was recorded at 60 percent while in 1970 and 1980, it was recorded at 48.8 percent and 22.2 percent respectively (NBS, 2010).

In 1993 and 1994, the major source of food accounted for about 30 percent of the GDP while livestock, forestry and wildlife, and fisheries accounted for 5 percent, 1.3 percent and 1.2 percent respectively (NBS, 2016). The major factor responsible for the decline in agriculture's contributions to GDP may be attributed to the neglect of the sector as a result of oil boom.

In 2016, NBS also estimates that 25 percent of the GDP of the Nigerian economy is composed of the agricultural sector and 70 percent of the Nigeria's labour force is employed in agricultural sector (NBS, 2016). It can therefore be seen that the growth and development of any nation depend to a large extent, on the development of agriculture. Nigeria which is naturally blessed and endowed with various natural resources such as good atmospheric condition, fertile and vast land, adequate rainfall, sufficient sunlight and so on, still hungry in the midst of plenty. This is as a result of underutilization or non-utilization of most of these natural endowments (Lawal, 2011).

Nigeria's agricultural sector has been faced with several problems which hindered the growth of the sector and also inhibited its potentials to be fully realized. These problems include; inadequacies in the supply and delivery of farm inputs, shortage of working capital, low level of technology, diseases and pest infestation, poor post-harvest processing, poor storage facilities, inconsistent and poorly conceived government policies, problems of pests and diseases, negative attitude of people towards farming due to low reward, inadequate agricultural education and extensions, poor transportation, lack of credit facilities, irrigation problems, lack of investment, lack of basic infrastructure, inaccessibility to loan facilities due to high bank interest rates, inadequate fertilizers and farm implements, environment hazards, labor and land use constraints.

Several researchers have investigated the impact of fiscal policy on agricultural sector development with mixed findings. For example, Zirra and Ezie (2017) studied the impact of government fiscal policy on agricultural sector output in Nigeria and discovered that government expenditure on agriculture has negative impact on agricultural sector. In another development, Aina and Omojola (2017) assessed the effect of government expenditure on agricultural output in Nigeria. The findings showed that there is a significant and positive increase of about 2 percent which is very low, between government expenditure on agriculture and agricultural output in Nigeria. However, as a result of the discrepancies in researchers' findings and with a strong view of how important fiscal policy instruments are in developing a nation, there is need to conduct further research in respect to the extent at which fiscal policy as impacted the growth of Agricultural output in Nigeria

\section{Literature Review \\ Theoretical Literature}

Musgrave Theory of Public Expenditure

Musgrave (1997) in his book on public finance in theory and practice argued that what matters most for government spending is how effective it is. If the so called "productive" category of government spending is not effective, it can have a negative impact on growth. The theory applied the analytic 
tools of price theory and of Keynesian macroeconomics to the issues of tax incidence (i.e. who bears the burden of taxes), of efficiency (i.e. measuring the losses caused by the distorting effects of taxes), and of achieving full employment. Musgrave divided the problem of public finance into three branches. The first branch was devoted to the problem of achieving full employment. Here, Musgrave applied the ideas of Keynesian fiscal policy to using tax reductions and government spending to increasing aggregate demand. The second branch focused on efficiency. That is how the revenue generated from taxation are efficiently allocated. The third branch then dealt with issues of redistribution to achieve a politically acceptable distribution of income. Therefore, public expenditure, if properly allocated and efficiently used, can have a wholesome effect on the economy.

\section{Wagner's Law/ Theory of Increasing State Activities}

This law named after the German political economist Adolph Wagner (1835-1917) is also known as the 'law of increasing state activity'. It was patterned after empirical analysis on Western Europe at the end of 19th century. The law suggests that public sector finance will increase as economic growth increases because new activities were extended. That is, there is increase in new activities which also brings about increase in output. He argued that there could be growth in the economy of a nation only if there is an increase in the state activities which could happen if government increases its spending. Wagner's law postulates three assumptions that; the extension of the functions of the states leads to an increase in public expenditure on administration and regulation of the economy; the development of modern industrial society would give rise to increasing political pressure for social progress and call for increased allowance for social consideration in the conduct of industry; and the rise in public expenditure will be more than proportional increase in the national income and will thus result in a relative expansion of the public sector. This theory is relevant in this study because of its emphasis on industrialization. One of the roles of agriculture is to provide raw materials for industries. This will enhance growth in the agricultural sector which will in turn contribute to the growth of the economy.

\section{Keynesian Theory of Public Expenditure}

The Keynesian school of thought suggested that government spending can contribute positively to sectoral growth (like the agricultural sector) in the economy. Thus, an increase in government expenditure is likely to lead to an increase in employment, profitability and investment through multiplier effects on aggregate demand. Consequently, government expenditure increases the aggregate demand which brings about an increased output depending on expenditure multipliers. Keynes regards public expenditures as an exogenous factor which can be utilized as a policy instruments to promote growth. This school of thought also believed that government intervention would help correct market failures. Keynes argued that during depression, increasing saving will not help but spending. Government will increase public spending, giving individuals purchasing power and producers will produce more. Thus, creating more employment for people. This is the multiplier effect that shows causality from public expenditure to national income (Keynes, 1936). The relevance of this theory to the Nigerian economy is that it describes how the government of the country can help bring about growth in the agricultural sector through its expenditure on the sector. 
INTERNATIONAL JOURNAL OF ACADEMIC RESEARCH IN BUSINESS AND SOCIAL SCIENCES Vol. 10, No. 8, 2020, E-ISSN: 2222-6990 @ 2020 HRMARS

\section{Empirical Literature}

Different studies have attempted to examine the impact of fiscal policy on agricultural sector development in different countries, using different techniques. Amongst many others are the following:

A study by Okoh, Amadi, Ojiya and Ani (2019) on the impact of fiscal policy on agricultural productivity in Nigeria reveals that government expenditure on agriculture was positive but statistically insignificant. The study used OLS estimation technique to check this impact. Lawal, Fidelis, Babajide, Obasaju, Oyetade, Lawal-Adedoyin, Ojeka and Olaniru (2018) examined the impact of fiscal policy on agricultural output in Nigeria. The study used ARDL estimation technique and the results of the findings show that government expenditure on agricultural output was statistically insignificant. Zirra and Ezie (2017) studied the impact of government fiscal policy on agricultural sector output in Nigeria. Fully modified OLS (FMOLS) method was used. In their findings, VAT was found to have influenced the growth of value of agricultural outputs positively and significantly, while government expenditure on agriculture is relatively low.

Kamil, Sevin and Festus (2017) investigated the impact of agricultural sector on economic growth of Nigeria. They employed Vector Error Correction Model to estimate the parameters of the model. The study revealed that agricultural output had a positive impact on the growth of the economy. Newettie (2017) examined the impact of government spending on agricultural growth in Zambia, Malawi, South Africa and Tanzania. The study utilized VECM to examine this impact and it was found out that government spending impact positively on agricultural output $n$ all the countries under study.

Aina and Omojola (2017) assessed the effect of government expenditure on agricultural output in Nigeria (1980-2013), using econometrics method of OLS and ECM. The short-run analysis shows that there is a significant and positive relationship between government expenditure on agriculture and agricultural production output. The long-run result shows that the coefficient of government expenditure on agricultural variable is rightly signed as well as the check variables. Shevchuk and Kopych also investigated the effects of fiscal policy on agricultural output and industry in Ukraine. The study employed SVAR model using quarterly data for 2001-2006 period. The results show positive effect of government spending on both agricultural and industrial output while government revenue was negative on agricultural output.

Abula and Ben (2016) investigated the impact of public agricultural expenditure on agricultural output in Nigeria, using ECM method to analyze the data. The results of the parsimonious ECM model showed that public agricultural expenditure has a significant negative impact on agricultural output. The study concluded that the negative impact of public agricultural expenditure on agricultural output may have resulted due to discrepancies that existed between the amount allocated to the agricultural sector and the amount actually spent on the sector. The study therefore recommended that monitoring agencies be established by the federal government to ensure that the amount allocated to the agricultural sector is actually and judiciously spent on the sector in Nigeria.

Ewubare and Eyitope (2015) examined the effect of public expenditure on agricultural production output in Nigeria. The methods of OLS, Johansen co-integration test and Error Correction Model was used to estimate the parameters. The results showed that the coefficient of determination was 0.9468 and the coefficient of the ECM appeared with negative sign and statistically significant. 
Okoh (2015) studied the impact of fiscal policy on the growth of agricultural sector in Nigeria (1981-2013), using Error Correction Model for the estimation. The findings from the study revealed that custom and excise duties though statistically significant, relates negatively with volume of agricultural outputs. However, VAT was found to have influenced the growth of the value of agricultural output positively and significantly, while government expenditure on agriculture has not been favourable.

Osuala (2014) examined the impact of fiscal policy on economic growth in Nigeria from 1986 to 2010 using the Ordinary Least Squares method of multivariate regression to analyze the loglinearized model. The Augmented Dickey-Fuller unit root test was employed to establish the stationarity of the variables while the General-to-Specific approach to Auto-Regressive Distributed Lag (ARDL) model was used for testing for the existence long-run and short-run equilibrium conditions. The findings show that there is an evidence of long run equilibrium relationship between fiscal policy and economic growth in Nigeria during the period studied. Specific fiscal policy variables that have significant and positive impact on economic growth in Nigeria are government recurrent and capital expenditures. Value Added tax and government total debts have no significant impact on the real GDP, only capital expenditure has short run equilibrium relationship with economic growth.

Ebere (2014) examined the impact of government expenditure on agriculture on economic growth in Nigeria. A time series data of 33 years sourced from the Central Bank of Nigeria was used. Ordinary Least Square (OLS) technique of data analysis was used in evaluating the secondary data. From the findings agricultural output, government expenditure and GDP are positively related. It was found that a significant relationship exist between government expenditure in the agricultural sector and the economic growth in Nigeria. The findings also revealed that the sector still encounter some problems like inadequate finance, poor infrastructure, and others.

Onyemaechi (2014) studied the impact of fiscal policy components on economic growth in Nigeria using Augmented Dickey-Fuller (ADF) test model and co-integration test and he found out that government expenditure on economic services and transfer payments have not yielded positive results as regards economic growth in Nigeria though statistically insignificant, expenditures on administration as well as social and community services yielded positive results in improving economic growth in Nigeria. He also used VAT and recurrent expenditure as proxy for taxation. It was found out that both impacted positively on economic growth.

Imoisi (2013) examined the problems surrounding the procedures of fiscal policy and their influence on economic growth in Nigeria from 1970 to 2009. Using the Ordinary Least squares (OLS) technique of multiple regression models, the estimated result showed that a positive relationship exists between real gross domestic product and government expenditure and taxes. This implies that government expenditure is a strong determinant of economic growth especially when properly directed towards the provision of adequate basic infrastructural facilities to stabilize investment activities. The regression result also showed that tax was not properly significant and this could largely be credited to poor tax administration in Nigeria and overdependence of the government earnings from crude oil in funding her projects. 
INTERNATIONAL JOURNAL OF ACADEMIC RESEARCH IN BUSINESS AND SOCIAL SCIENCES

Vol. 10, No. 8, 2020, E-ISSN: 2222-6990 @ 2020 HRMARS

\section{Methodology}

\section{Model Specification}

The model was analyzed using an econometric model of vector error correction model to test the relationship between dependent variable and independent variables. In order to capture the impact of fiscal policy on agricultural sector development, this study modified the empirical work of Ewubare and Eyitope (2015). The Agricultural Output (AGOUT) was used as the proxy for dependent variable (Agricultural Sector Development) while Agricultural Capital Expenditure (CEXP), Agricultural Recurrent Expenditure (REXP) and Personal Income Tax (PIT) are the independent variables used in the study. The specification of the variables in the work of Ewubare \& Eyitope (2015) is given as;

$A G R_{t}=\beta_{0}+\beta_{1} G E A_{t}+\beta_{2} D B A_{t}+\beta_{3} G C E_{t}+\mu_{t}$

Where, $A G R_{t}=$ Agricultural output

$\mathrm{GEA}_{\mathrm{t}}=$ Government Capital Expenditure on Agriculture

$D_{B A}=$ Deposit Money banks loan

$\mathrm{GCE}_{\mathrm{t}}=$ Government Recurrent Expenditure on Agriculture.

The variable (DBA) in the work of Ewubare and Eyitope (2015) was dropped in this study with little modification because even in their work, it did not have any significant impact on agricultural output in Nigeria. The model for this study is therefore given below;

The equation (3.2) is the functional form of the variables specified in the model.

AGOUT=f (CEXP, REXP, PIT) .2

The stochastic form of the model is given in equation (3.3) as:

AGOUTt $=\beta 0+\beta_{1}$ CEXPt $+\beta_{2}$ REXPt $+\beta 3 P I T+\mu t$ 3

Equation (3) can be expressed in the log-linear function. Taking the natural logarithm of the model will enable the coefficients of the model to be interpreted as elasticities. The model is then specified as;

$\operatorname{InAGOUT} t=\operatorname{In} \beta_{0}+\beta_{1} \operatorname{lnCEXP}_{t}+\beta_{2} \operatorname{InREXP} t+\beta_{3} P I T_{t}+\mu_{t} \ldots \ldots \ldots \ldots \ldots \ldots \ldots . . . . \ldots$

Where,

AGOUT = Agricultural Output

CEXP = Agricultural Capital Expenditure

REXP = Agricultural Recurrent Expenditure

$\mathrm{PIT}=$ Personal Income Tax

$\mu=$ Stochastic Error Term which denotes other explanatory variables not specified in the model.

$\beta_{0}=$ Intercept

$\beta_{1}, \beta_{2}, \beta_{3}$, = Slope of the Coefficients of the independent variables to be determined.

In = Natural log

\section{Source of Data}

This study used secondary data source. The data for all the variables were obtained from Central Bank of Nigeria Statistical Bulletins volume 26, December 2017. Time series data were collected for the period under review (1980-2017) on Agricultural Output being the dependent variable while Agricultural Recurrent Expenditure, Agricultural Capital Expenditure and Personal Income Tax are the independent variables. 


\section{Techniques of Analysis}

The data analysis technique employed in estimating the parameters in this study involved the use of error correction model. Error Correction Model was used to tie the short-run behavior to its long-run value. This model examines the long-run and short-run dynamic relationship. However, estimation of the model specified may yield spurious regression if the variables are not stationary. Thus, to check this problem, the unit root test, using the Augmented Dickey Fuller (ADF) test was employed. Also, the co-integration test was carried out, using Johansen Co- integration Test in order to test for long-run equilibrium relationship between the series of the same order of integration.

\section{Data Analysis and Interpretation of Results}

This study examines time series data from 1980-2017. The econometric analysis involves three basic steps. First, the unit root test examines the stationarity of the data. Second, the Johansen cointegration test investigates the long-run relationship between the variables. While the Vector Error Correction Model (VECM) is used to determine the speed of adjustment of the variables. That is, how errors generated in the short-run are corrected in the long-run equilibrium path. Therefore, in this chapter, the data are analyzed and the results obtained from the analysis are discussed. The data gathered for this study as well as the regression results are reported in appendix.

\section{Unit Root Test Result}

In order to avoid the possibility of having spurious regression results, the variables were tested for stationarity to ascertain the order of their integration. The Augmented Dickey-Fuller unit root stationarity test was utilized. This is to find out if the relationship between economic variables is spurious. The decision rule is:

Decision rule:

If $t^{*}>A D F$ critical value, $==>$ do not reject null hypothesis, i.e., unit root exists.

If $t^{*}<A D F$ critical value, $==>$ reject null hypothesis, i.e., unit root does not exist.

Table 1

\begin{tabular}{lccccl}
\multicolumn{4}{l}{ Augmented Dickey-Fuller Unit Root Test } \\
\hline Variables & ADF Stat. & $\begin{array}{l}\text { Critical } \\
\text { Value (5\%) }\end{array}$ & $\begin{array}{l}\text { Order of } \\
\text { Integratio }\end{array}$ & Prob & Remarks \\
\hline $\begin{array}{l}\text { AGOUT } \\
\text { CEXP } \\
\text { REXP }\end{array}$ & -10.31718 & -2.945842 & $1(1)$ & 0.0000 & $\begin{array}{l}\text { Stationar } \\
\text { y }\end{array}$ \\
PIT & -7.238338 & -2.945842 & $1(1)$ & 0.0000 & $\begin{array}{l}\text { Stationar } \\
\text { y }\end{array}$ \\
& -8.452734 & -2.945842 & $1(1)$ & 0.0000 & $\begin{array}{l}\text { Stationar } \\
\text { y }\end{array}$ \\
& -9.563264 & -2.945842 & $1(1)$ & 0.0000 & Stationar \\
\hline
\end{tabular}

Source: Researcher's computation using E-views, 2020.

Table 1 presents the result of the unit root test. The degrees of integration of the variables employed in the test were estimated and was integrated of order one I (1) using the Augmented 
INTERNATIONAL JOURNAL OF ACADEMIC RESEARCH IN BUSINESS AND SOCIAL SCIENCES Vol. 10, No. 8, 2020, E-ISSN: 2222-6990 @ 2020 HRMARS

Dickey-Fuller unit root test. This study requires same order of stationary for the time series data because it is prerequisite in co-integration analysis.

Going by the results, at 1st difference, the ADF test reveals that all the variables: Agricultural Output (AGOUT), Agricultural Capital Expenditure (CEXP), Agricultural Recurrent Expenditure (REXP) and Personal Income Tax (PIT) are stationary at 5 percent. This is because the ADF statistics value in absolute term for all the variables is greater than the critical value. Further evidence of stationarity can also be seen from the result of the $p$-value which is less than that $5 \%(0.05)$ for all variables.

\section{Lag Selection Criteria}

The VAR Lag Order selection criteria was carried out in order to ascertain the appropriate lag selection for the study. The result is presented in table 2

Table 2

VAR Lag Order Selection Criteria

\begin{tabular}{llllll}
\hline Lag & LogL & LR & FPE & AIC & SC \\
\hline 0 & -222.4803 & NA & 0.279783 & 12.91557 & 13.13551 \\
1 & -120.2430 & $178.7288^{*}$ & $0.002947^{*}$ & 8.346833 & $9.666432^{*}$ \\
2 & -93.81653 & 36.70341 & 0.002965 & $8.267585^{*}$ & 10.68685
\end{tabular}

Researcher's computation using Eviews, 2020

* indicates lag order selected by the criterion

LR: sequential modified LR test statistic (each test at 5\% level) FPE:

Final prediction error

AIC: Akaike information criterion SC:

Schwarz information criterion

HQ: Hannan-Quinn information criterion

Table 2 presents the VAR lag selection criteria for all the variables. The selection criteria result shows that the likelihood ratio, the final prediction error, the Schwarz and Hannan criteria selected lag 1 as shown by the asterisk* at 5\% significance level, while the Akaike information criterion selected lag 2 . The rule of thumb is that, the model that gives the lowest value of these criteria should be selected. Therefore, since the FPE: Final prediction error gives the least figure at lag 1, the study shall adopt lag 1 as the optimum lag value for the study.

\section{Co-integration Test Result}

Having established that the variables are integrated of the same order, the researcher proceeds to testing for co-integration. The Johansen-Juselius Maximum Likelhood procedure was applied in determining the co-integrating rank of the system and the number of common stochastic trend 
INTERNATIONAL JOURNAL OF ACADEMIC RESEARCH IN BUSINESS AND SOCIAL SCIENCES

Vol. 10, No. 8, 2020, E-ISSN: 2222-6990 @ 2020 HRMARS

driving the entire system. The concept of co-integration is relevant to the problem of the determination of long-run equilibrium relationship.

Table 3

Johansen Co-integration Test Result

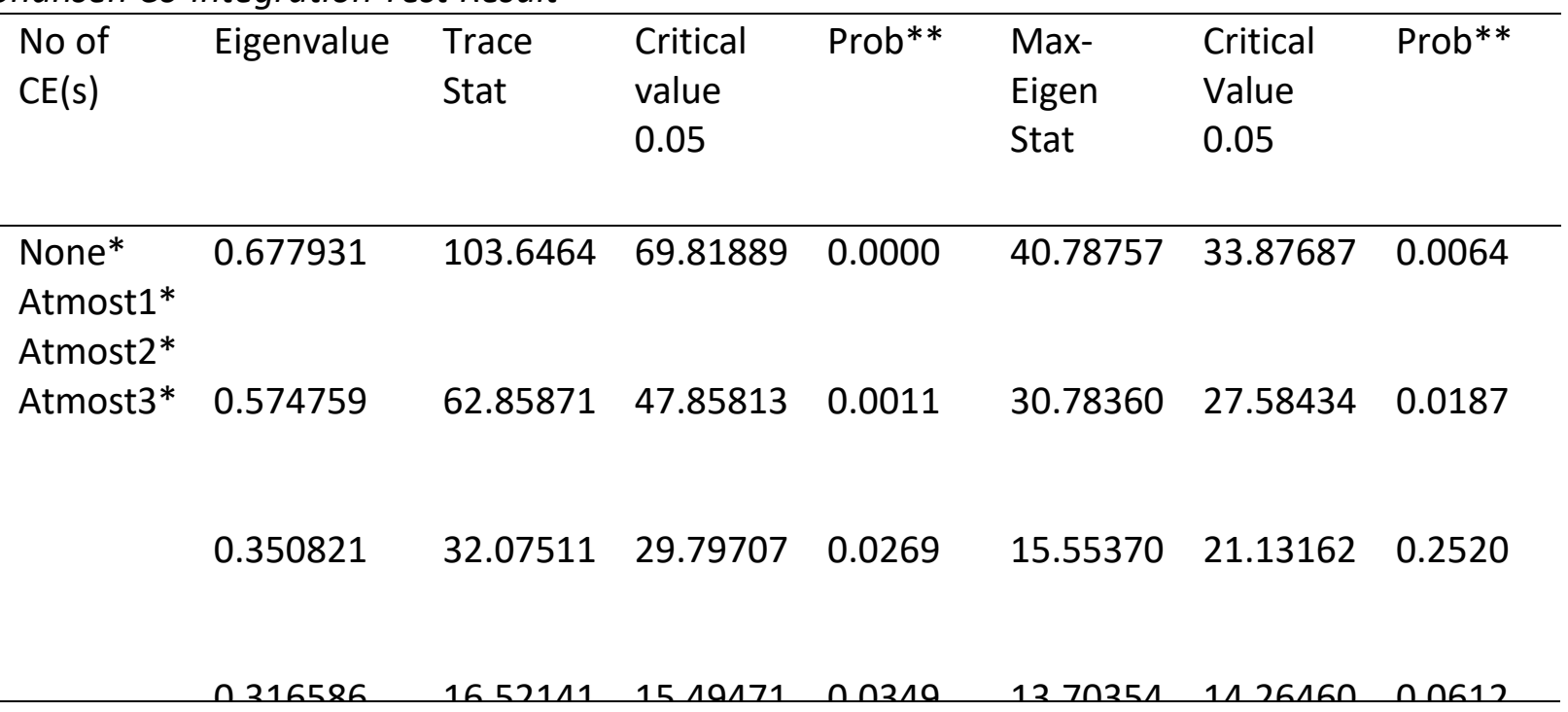

Source: Researcher's computation using Eviews, 2020

Table 3 presents the Johansen Co-integration test result. The condition for a long-run cointegrating vector is that the trace statistics and the Max-Eigen Statistics (Likelihood ratio) must be greater than critical value at $5 \%$. The result of the co-integration test conducted indicates the existence of three co-integrating relationship among the variables at $5 \%$ level of significance. The Max-Eigenvalue test indicates on e co-integrating relationship at the 0.05 level. This denotes rejection of the hypothesis at the 0.05 level because the trace statistic and the max- eigenvalue statistic are greater than the critical values. Thus, it can be concluded that there exists a long-run relationship among the variables. The null hypothesis which states that, there is no long-run relationship between fiscal policy and agricultural output in Nigeria can therefore be rejected. Therefore, given the co-integration result, Vector Error Correlation Model (VECM) is appropriate for the estimation of the model. The researcher then proceeds to estimate the variables using the Vector Error Correction Model (VECM) designed for use with non-stationary time series that are known to be co-integrated.

\section{Vector Error Correction Model}

The Vector Error Correction coefficient is the speed of adjustment factor which shows how fast the system adjusts in order to restore equilibrium. It also shows the reconciliation of the variables over time right from when disequilibrium is restored. The result of the Vector Error Correction Model is indicated in table 4. 
INTERNATIONAL JOURNAL OF ACADEMIC RESEARCH IN BUSINESS AND SOCIAL SCIENCES Vol. 10, No. 8, 2020, E-ISSN: 2222-6990 @ 2020 HRMARS

Table 4

Summary of Regression Result

\begin{tabular}{ccccc}
\hline \multicolumn{2}{l}{ Dependent Variable: AGOUT } & & & \\
\hline Variables & Coefficent & Std Error & t-Statistic & Prob* \\
\hline AGOUT(-1) & 0.426134 & 0.123708 & 3.444599 & 0.0018 \\
CEXP(-1) & 0.327902 & 0.169143 & 1.938609 & 0.0423 \\
REXP(-1) & 0.031659 & 0.120409 & 0.262930 & 0.0245 \\
PIT(-1) & -0.044085 & 0.094775 & -0.465161 & 0.6453 \\
ECM(-1) & -0.016390 & 0.091975 & -0.178201 & 0.04598 \\
C & 0.082820 & 0.100971 & 0.820028 & 0.4188 \\
\hline $\begin{array}{l}\text { R-squared=0.640431 } \\
\text { Prob(F-statistic) }\end{array}$ & $=0.009902$ & $\begin{array}{l}\text { Adj.R-squared=0.620520 } \\
\text { Durbin Watson Stat =2.362971 }\end{array}$ & F-statistic=3.506196
\end{tabular}

Source: Researcher's computation using Eviews Software, 2020.

The summary of the regression result as presented in table 4 shows that the coefficient of the Error Correction Model (ECM) has the expected negative sign and at the same time statistically significant at $5 \%$ level of significance. The coefficient of the Error Correction Model (ECM) is 0.216390 and the $p$-value is less 5 percent alpha level which shows that it is statistically significant. The value of -0.22 shows that about 22 percent of the deviation from long-run equilibrium is restored annually. Therefore, any shock to the system is bound to be corrected within a year up to the tune of 22 percent. Also, the sign of the Error Correction Model (ECM) which is negative and statistically significant further validates long-run equilibrium relationship among the series.

Going by the figures of the regression result, there is a positive relationship of 0.426134 between the past value of agricultural output and its present value. This implies that a percentage increase in the past value of AGOUT will result in approximately 0.43 increase in its present value. Moreover, the $p$-value is 0.0018 , and it is statistically significant at $5 \%$ level of significance.

The coefficient of government capital expenditure is 0.327902 . This means that government capital expenditure has a positive effect of approximately 0.33 on agricultural output. The implication of this is that, a percentage increase in government capital expenditure will result in approximately 0.33 increase in agricultural output. The result of the p-value $(0.0423)$ which is less than 0.05 also reveals that the effect is statistically significant. Going by this result, the study therefore rejects the null hypothesis which states that government capital expenditure does not have significant impact on agricultural output in Nigeria. This simply means that government expenditure is a strong determinant of agricultural output especially when properly directed towards the provision of adequate basic infrastructural facilities to stabilize investment activities. This finding agrees with earlier researcher like (Aina \& Omojola, 2017) who also found a positive and significant impact of government capital expenditure on agricultural output in Nigeria. The 
INTERNATIONAL JOURNAL OF ACADEMIC RESEARCH IN BUSINESS AND SOCIAL SCIENCES Vol. 10, No. 8, 2020, E-ISSN: 2222-6990 @ 2020 HRMARS

coefficient of government capital expenditure in the work of Aina and Omojola(2017) was 28 percent, meaning that this study shows a 5 percent increase.

The study reveals the coefficient of recurrent expenditure to be 0.0327902. This implies that government recurrent expenditure has a positive impact on agricultural output. This result satisfies the a-priori expectation of the study. The variable is also statistically significant at $5 \%$ level of significance since the $p$-value is less than 0.05 . However, personal income tax shows a coefficient of -0.044085 which implies that a percentage increase in personal income tax will result in approximately 0.04 decrease in agricultural output in Nigeria, However, the result of the p-value which stands at 0.6453 further shows that the impact is not statistically significant, since the $p$ value is greater than 0.05 (i.e. at $5 \%$ level of significance). Therefore, this study accepts the null hypothesis which states that personal income tax does not have a significant impact on agricultural output in Nigeria within the period under study.

Furthermore, it can be seen from the study that value of the autonomous- i.e. the intercept stands at approximately 0.08 . This is the value of agricultural output when the independent variables: government capital expenditure, government recurrent expenditure and personal income tax are held constant or zero.

The $\left(R^{2}\right)$ which is the coefficient of determination or measure of goodness of fit gives approximately 0.64 . This implies that $64 \%$ of total variation in agricultural output is influenced by the independent variables: government capital expenditure, government recurrent expenditure and personal income. Thus, the remaining $36 \%$ can be attributed to other factors that also influence the dependent variable (agricultural output) which are not captured in the model The F-statistics is used to test for simultaneous significance of all the estimated parameters. However, the lower the probability value of obtaining the f-statistic, the better the overall significance of the regression. The result obtained from the regression result reveals that the Prob(F-statistic) $=0.009902$ at $5 \%$ level of significance. This implies that the explanatory variables: government capital expenditure, government recurrent expenditure and personal income tax are simultaneously significant in explaining the variation in agricultural output. The computed D.W. (Durbin-Watson) in model one is 2.362971 , meaning that the model is free from autocorrelation since it is greater than 2 .

\section{Forecast Error Variance Decomposition}

To further examine the short-run dynamics between fiscal policy and agricultural output in Nigeria. The researcher estimated forecast error variance decomposition derived from the VAR which was estimated earlier. Variance Decomposition indicates the information about the percentage of the movements in a variable due to its own shocks versus shocks to the other variables in the system. The variance decomposition is useful in discerning the degree of exogeneity of the variables and the dynamic responses of the variables beyond the sample period. The results of the Variance Decomposition for all variables: agricultural output, government recurrent expenditure, Government capital expenditure and personal income tax are presented as thus: 
INTERNATIONAL JOURNAL OF ACADEMIC RESEARCH IN BUSINESS AND SOCIAL SCIENCES Vol. 10, No. 8, 2020, E-ISSN: 2222-6990 @ 2020 HRMARS

\section{Table $5 a$}

Variance Decomposition of AGOUT:

\begin{tabular}{llllll}
\hline Period & SE & AGOUT & CEXP & REXP & PIT \\
\hline 1 & 0.500758 & 100.0000 & 0.000000 & 0.000000 & 0.000000 \\
2 & 0.622131 & 90.39410 & 9.156463 & 0.253378 & 0.176796 \\
3 & 0.740789 & 91.96793 & 6.468200 & 0.891491 & 0.143128 \\
4 & 0.842134 & 91.39942 & 5.005848 & 1.165801 & 0.943028 \\
5 & 0.924106 & 91.91000 & 4.795368 & 0.969070 & 0.855210 \\
6 & 0.999038 & 92.05773 & 4.876270 & 0.898859 & 0.755124 \\
7 & 1.070160 & 92.54430 & 4.376014 & 0.792663 & 0.729558 \\
8 & 1.137312 & 92.82827 & 3.979014 & 0.712989 & 0.774131 \\
9 & 1.199275 & 93.01974 & 3.865923 & 0.642173 & 0.754178 \\
10 & 1.258186 & 93.19451 & 3.764866 & 0.594089 & 0.722317 \\
\hline
\end{tabular}

Source:Researcher's computation using Eviews,2020.

From table 5a, the predominant sources of variation in agricultural output can be attributed to its own shock, for instance, in period 1, 100\% percentage variation in agricultural output is attributed to its own shock, the figure later dropped to about $91 \%$ in period 4 while the remaining 9 is caused by shock from other variables: government recurrent expenditure, Government capital expenditure and personal income tax where government recurrent expenditure as the highest percentage (5\%) among the other variables. In year 10, the variation of agricultural output later increases to $93 \%$ while the remaining $7 \%$ can be attributed to other variables. 
INTERNATIONAL JOURNAL OF ACADEMIC RESEARCH IN BUSINESS AND SOCIAL SCIENCES Vol. 10, No. 8, 2020, E-ISSN: 2222-6990 @ 2020 HRMARS

Table 5b

Variance Decomposition of CEXP

\begin{tabular}{llllll}
\hline Period & SE & AGOUT & CEXP & REXP & PIT \\
\hline 1 & 0.525732 & 3.786559 & 96.21344 & 0.000000 & 0.000000 \\
2 & 0.607558 & 5.266500 & 80.68468 & 3.872469 & 0.039400 \\
3 & 0.776473 & 7.257723 & 50.04529 & 9.264823 & 5.569847 \\
4 & 0.874082 & 7.036422 & 43.84745 & 10.58703 & 7.239601 \\
5 & 0.950454 & 6.728945 & 47.05244 & 8.956440 & 6.310569 \\
6 & 1.010283 & 7.101242 & 44.11824 & 8.086269 & 6.295455 \\
7 & 1.080968 & 7.402795 & 39.42060 & 8.365704 & 6.989018 \\
8 & 1.142496 & 7.420670 & 38.02210 & 8.238963 & 7.174530 \\
9 & 1.196055 & 7.443253 & 37.88386 & 7.704715 & 7.006137 \\
10 & 1.247460 & 7.583531 & 36.52267 & 7.404506 & 7.059515
\end{tabular}

Source: Researcher's computation using the Eviews Software, 2020

Table $5 b$ presents the variance decomposition for government capital expenditure. It is evident that within first 4 periods, more than $50 \%$ variation in government capital expenditure can be attributed to its own shock. In period 10, the figure dropped to $36 \%$ which shows that $44 \%$ variation in government capital expenditure is caused by other variables.

Table 5c.

Variance Decomposition of REXP

\begin{tabular}{llllll}
\hline Period & SE & AGOUT & CEXP & REXP & PIT \\
\hline 1 & 0.751231 & 0.678614 & 0.000363 & 99.32102 & 0.000000 \\
2 & 0.911100 & 0.583341 & 0.520191 & 96.59938 & 1.730150 \\
3 & 1.091985 & 0.819028 & 1.018474 & 96.01550 & 1.241989 \\
4 & 1.234106 & 0.766791 & 0.928390 & 95.50129 & 1.441496 \\
5 & 1.353778 & 0.823707 & 0.993472 & 95.20712 & 1.252654 \\
6 & 1.472903 & 0.833004 & 1.086492 & 94.93896 & 1.274868 \\
7 & 1.581064 & 0.854578 & 1.155986 & 94.76244 & 1.220997 \\
8 & 1.681719 & 0.858254 & 1.157034 & 94.64884 & 1.196611 \\
9 & 1.775213 & 0.868148 & 1.178510 & 94.54563 & 1.162294 \\
10 & 1.865886 & 0.875771 & 1.210159 & 94.45544 & 1.147654
\end{tabular}

Source: Researcher's computation using Eviews, 2020 
INTERNATIONAL JOURNAL OF ACADEMIC RESEARCH IN BUSINESS AND SOCIAL SCIENCES Vol. 10, No. 8, 2020, E-ISSN: 2222-6990 @ 2020 HRMARS

Table 5c presents the variance decomposition for Government recurrent expenditure. The result reveals that the predominantly source of variation in REXP is caused by its own shock. At all the period, more than $90 \%$ variation in government recurrent expenditure was caused by its own shock. For instance, at period 4, about 95\% variation in REXP was caused by its own shock, while the remaining $5 \%$ was caused by other variables. Also, at period 10 , just about $6 \%$ can be attributed to other variables.

Table 5d

Variance Decomposition of PIT:

\begin{tabular}{llllll}
\hline Period & SE & AGOUT & CEXP & REXP & PIT \\
\hline & & & & & \\
\hline & 0.72330 & 0.201123 & 0.749041 & 0.723553 & 98.30133 \\
2 & 0.84861 & 0.223159 & 13.24947 & 6.461812 & 77.31871 \\
3 & 1.03121 & 0.543390 & 18.70445 & 10.71351 & 66.75137 \\
4 & 1.11103 & 0.470040 & 17.26715 & 12.62746 & 66.59639 \\
5 & 1.21013 & 0.448905 & 16.52863 & 11.62127 & 68.67204 \\
6 & 1.30473 & 0.464182 & 18.02258 & 12.53940 & 66.01633 \\
7 & 1.39279 & 0.471471 & 18.63770 & 13.38415 & 64.48743 \\
8 & 1.46637 & 0.452290 & 18.31114 & 13.66939 & 64.64033 \\
9 & 1.53945 & 0.445313 & 18.29751 & 13.64283 & 64.74031 \\
10 & 1.61242 & 0.448558 & 18.66221 & 13.91681 & 64.06266 \\
\hline
\end{tabular}

Source: Researcher's computation using Eviews, 2020

Table 5d presents the Variance Decomposition for Personal Income Tax. At period 1, 98\% variation in PIT can be attributed to its own shock while the remaining $2 \%$ is attributed to other variables in the model. At period 4 , it drops to $66 \%$ from its own shock while agricultural output is $0.47 \%$, government capital expenditure $17 \%$ and recurrent expenditure $12 \%$. This shows that among the other variables, government capital expenditure has the highest influence of shock on personal income tax.

\section{Heteroskedasticity Test}

Heteroskedasticity is a term used to describe the situation when the variance of the residuals from a model is not constant. Breusch-Pagan-Godfrey test was used to test for the presence of heteroskedasticity. The result of the heteroskedasticity is presented in Table 5.

Table 6

Heteroskedasticity Test: Breusch-Pagan-Godfrey

\begin{tabular}{llll}
\hline F-statitics & 0.476436 & Prob F(10,25) & 0.8895 \\
\hline Obs R-squared & 5.762492 & Prob. Chi-Square (10) & 0.8348 \\
Scaled explained SS & 15.60899 & Prob. Chi-Square (10) & 0.1114 \\
\hline
\end{tabular}

Source: Researcher's computation using Eviews, 2020 
INTERNATIONAL JOURNAL OF ACADEMIC RESEARCH IN BUSINESS AND SOCIAL SCIENCES Vol. 10, No. 8, 2020, E-ISSN: 2222-6990 @ 2020 HRMARS

Table 6 presents the Heteroskedasticity test. Breusch-Pagan-Godfrey test was used to test if residual is heteroscedastic. Here, $\mathrm{H}_{0}=$ There is no heteroskedasticity in the model is the null hypothesis and $\mathrm{H}_{1}=$ There is heteroskedasticity in the model is the alternative hypothesis. The decision rule is if the $\mathrm{p}$ value is less than 0.05 ( $5 \%$ level of significance) we reject $\mathrm{H}_{0}$; otherwise, we accept $\mathrm{H}_{0}$ and reject $\mathrm{H}_{1}$. From the heteroskedasticity test result, the $\mathrm{p}$-value is 0.8348 this is greater than 0.05 (5\% level of significance) and is significant. $\mathrm{HO}$ is therefore accepted and $\mathrm{H} 1$ rejected, i.e., there is no heteroskedasticity in the model, thus indicating that the variance of the error term does not change in response to a change in the values of the independent variables

\section{Conclusion and Recommendations Conclusion}

This study seeks to examine the impact of fiscal policy on agricultural sector development in Nigeria. From the findings of this study, it can be ascertained that agriculture is beneficial and plays a significant role in the development process of Nigerian economy. The roles of agriculture in economic growth and development in any nation is crucial and it is a sign of prosperity and development. Agriculture will continue to contribute to the major part of the Gross Domestic Product (GDP) for many years to come. Therefore, increasing budgetary allocation to agricultural sector in order to enhance the speed at which the sector grows as well as managing the tax system effectively will go a long way in the development process of a nation.

It is believed that this study is relevant to stakeholders, and policy makers as it throws more light on the role of fiscal policy on agricultural output over the years for the purpose of providing evidence based recommendations on how fiscal policy can further be improved to accelerate the growth of agricultural output in Nigeria. Moreover, it would be of great benefit to students and researchers in the course of their study by adding to the existing knowledge, thus widening their scope in the field of research and providing a framework which further research can be carried out.

\section{Recommendations}

Having examined the impact of fiscal policy on agricultural sector development in Nigeria, the following recommendations were made based on the findings of the study:

i. Since agriculture is very paramount to the development process of any nation, government should increase her capital budgetary allocation to this sector in a consistent manner and also ensure the effective utilization of such funds so as to achieve the targeted aim of developing agricultural sector and the nation at large.

ii. Government should ensure that Nigerian economy is diversified, in other words, crude oil should not be the mainstay of Nigerian economy. Government should as well make agricultural sector a priority. This would serve as another source of generating revenue other than revenue from the oil sector.

iii. Expansionary fiscal policy measures should be encouraged by the government because it will play a vital role in the growth of agriculture in Nigeria. If this measure is put in place, agriculturalists would be able to have more income to invest in agriculture. Even in the part of the government, when more money is allocated and effectively implemented in agriculture, there would be increase in agricultural output and this would increase the nation's gross domestic product (GDP). 
INTERNATIONAL JOURNAL OF ACADEMIC RESEARCH IN BUSINESS AND SOCIAL SCIENCES

Vol. 10, No. 8, 2020, E-ISSN: 2222-6990 @ 2020 HRMARS

iv. Government should ensure that the policies formulated to strengthen agricultural sector are properly and efficiently implemented. This would enhance food security and also mitigate against poverty.

\section{References}

Adam, S. (1776). The Wealth of Nations. William Straham: Scotland.

Abula, M., and Ben, D. M. (2016). Impact of Public Agricultural Expenditure on Agricultural Output in Nigeria (1981-2014). Asian Journal of Agricultural Extension, Economics and Sociology, 11(2), 1-10.

Ahmed, M. (2013). Government Expenditure on Agriculture and Agricultural Output in Nigeria. Journal of Economics and International Finance, 5(5), 35-41.

Akala, S. (2010). The Impact of Government Spending on Agriculture. Journal of Social Science and Humanities, 4(2), 14-19.

Akinboyo, O. I. (2008). Five Decades of Agricultural Policies: What Role Has Statistics Played? CBN Statistical Bulletin, 32, 134-165.

Aina, G. O., and Omojola, J. T. (2017). Assessment of the Effect of Government Expenditure on Agricultural Output in Nigeria (1980-2013). International Journal of Innovative Agriculture and Biology Research, 5(4), 1-7.

Atawodi, O. W., and Ojeka, S. A. (2012). Relationship between Tax Policy, Growth of SMEs and the Nigerian Economy. International Journal of Business and Management,7(13),64-70.

Ayuba, A. (2014). Impact of Non-oil Tax Revenue on Economic Growth: The Nigerian Perspective. International Journal of Finance And Accounting, 3(5), 303-309.

Bukie, O. H., \&Adejumo, T. O. (2013). The Effects of Tax Revenue on Economic Growth in Nigeria (1970-2011). International Journal of Humanities and Social Science Invention,2(6), 18-25.

CBN Report. (2011). Fiscal Policy and Government Finance. CBN Annual Report, December 2011.

Chandrasekaran, B., Annadurai, K., and Somasundaram, E. (2010). A Textbook of Agronomy. New Age International Limited. New Delhi.

Ebere, A. (2014). The Impact of Government Expenditure on Agriculture on Economic Growth in Nigeria. International Journal of Humanities and Social Science, 2(1), 50-62.

Ebomche, C. (2010). Agriculture and Economic Growth in Nigeria. Journal of Economics and Behavioral Studies, 4(7), 345-349.

Ewubare, D. B., and Eyitope, J. A. (2015). The Effect of Public Expenditure on Agricultural Production Output in Nigeria. Journal of Research in Humanities And Social Science, 3(11), 7-23.

FAMAN. (2011). Policy and Agricultural Development in Nigeria: Challenges and Prospects. Proceedings of the $25^{\text {th }}$ Farm Management Association of Nigeria (FAMAN) Conference. Held At The Federal College Of Agriculture, Akure.

FIRS. (2017). Taxation Reform in Democratic Nigeria. FGN, Abuja.

Iganiga, B. O., and Unemhilin, D. O. (2011). The Impact of Federal Government Agricultural Expenditure on Agricultural Output in Nigeria. Journal of Economics, 2(2),81-88.

Imoisi, A. (2013). An Appraisal of Fiscal Policy Measures and Its Implication for Growth of the Nigerian Economy (1970-2009). Advances in Management and Applied Economics, 3(4), $193-$ 204. 
INTERNATIONAL JOURNAL OF ACADEMIC RESEARCH IN BUSINESS AND SOCIAL SCIENCES Vol. 10, No. 8, 2020, E-ISSN: 2222-6990 @ 2020 HRMARS

Iwuji, G. I. (2011). Creating Awareness On Tax Matters For Small And Medium Units. Retrieved From: http://www.docstoc.com/19747636/Creating-Small-Medium-Enterprises-Tax- MattersAwareness

Jhingan, M. L. (2011). Macroeconomic Theory $\left(10^{\text {th }}\right.$ ed). Delhi: Vrinda Publications Limited. Kamil, S., Sevin, U. and Festus, V.B. (2017). The Contribution of Agricultural Sector on Economic Growth of Nigeria. International Journal of Economics and Financial Issues, $\quad$ 7(1), 547552.

Keynes, J. M.(1936). General Theory of Employment, Interest and Money. London: Palgrave Macmillian.

Lawal, W. A. (2011). An Analysis of Government Spending On Agricultural Sector and its Contribution To GDP In Nigeria. International Journal of Business and Social Science, 2(20), 35-42.

Lawal, A. I., Fidelis, E. O., Babajide, A. A., Obasaju, B. O., Oyetade, O., Lawal-Adedoyin, B., Ojeka, J. D., and Olaniru, O. S. (2018). The Impact of Fiscal Policy on Agricultural Output in Nigeria. Journal of Environmental Management and Tourism, 9(7), pp. 1428-1442.

Loto, M. A. (2012). Impact of Government Sectoral Expenditure on Economic Growth. Journal of Economics and International Finance, 3(11),646-652.

Moghaddasi, S. (2008). Agricultural Public Spending in Nigeria. IFPRI Discussion paper, 00789, September.

Musgrave, R. (1997). Public Finance in Theory and Practice. New York: McGraw-Hill. NBS (2010). The Review of the Nigerian Economy. FGN, Abuja.

NBS. (2016). Agricultural Statistics. FGN, Abuja.

NEPAD (New Partnership For African Development): CAADP(Comprehensive Africa Agricultural Development Programme)(2011).[Online] Available: http://nepad-caadp.net $\quad\left(^{\text {th }}\right.$ November 2011).

Ogbole, F. O., Amadi, S. N., and Essi, I. D. (2011). Fiscal Policy: Its Impact On Economic Growth In Nigeria (1970-2006). Journal of Economics and International Finance, 3,407-417.

Oguamanam, M. J. (2011). The Growth of The Banking Industry in Nigeria, Presented At The Annual Seminar of The Chartered Institute of Bankers' House, Lagos-State.

Ojede, A., Amin, M., and Daigyo, S. (2013). Macroeconomic Policy Reforms and Productivity Growth in African Agriculture. Journal of Contemporary Policy, 31(4), 814-830.

Oji-Okoro, I. (2011). Analysis of the Contribution of Agricultural Sector on the Nigerian Economic Development. World Review Business Research, 1(1), 191-200.

Okoh, A. S. (2015). Impact of Fiscal Policy on the Growth of Agricultural Sector in Nigeria (19812013). European Journal f Education and Development Psychology, 3(4), 1-17.

Okoh, S. A., Amadi, U., Ojiya, E. A., and Ani, E. C. (2019). Impact of Fiscal Policy on Agricultural Productivity in Nigeria: An Empirical Analysis. Journal of Business School, 2(3), pp. 7-27.

Okoro, A.(2013). Government Spending and Economic Growth in Nigeria (1980-2011). Global Journal of Management and Business Research, Economics and Commerce, 13(5), 21-30.

Olorunfemi, S. (2008). Public Investment and Economic Growth in Nigeria: An Autoregressive Model. Journal of International Finance and Economics, 2(4), 8-12.

Onyemachi, J.(2014).Impact of Fiscal Policy Components On Economic Growth In Nigeria: An Empirical Trend Analysis. Journal of Business and Management Review, 4(1),1-19. 
INTERNATIONAL JOURNAL OF ACADEMIC RESEARCH IN BUSINESS AND SOCIAL SCIENCES

Vol. 10, No. 8, 2020, E-ISSN: 2222-6990 @ 2020 HRMARS

Osuala, A. N.(2014). Impact of Fiscal Policy on Economic Growth of Nigeria. $6^{\text {th }}$ Annual American Business Research Conference, New York.

Rimando, S. A. (2004). Agricultural Expenditure and Economic Growth in Nigeria. Journal of Economics and Social Science, 12, 7-12.

Saeed, K. P., and Somaye, S. (2012). Relationship between government spending and revenue: Evidence from oil exporting countries. International Journal of Economics and Management Engineering (IJEME), 2(2): 33-35.

Sikiru, J. B., and Umaru, A. (2012). Fiscal Policy and Economic Growth Relationship in Nigeria. International Journal of Business and Social Science, 17(2), 244-249.

Siyan, P., and Debayo, F. O. (2005). The Agricultural Sector in Nigeria: The Way Forward. CBN Bulletin, 21, 14-25.

Solow, R. M. (1956). A Contribution to the Theory of Economic Growth. Princeton: Princeton University Press, pp 26-76.

Wagner, A.(1893). The Foundation of the Political Economy ( $3^{r d}$ ed). Leipzig: Germany.

Wahab, T. (2011). Analysis of Government Spending on Economic Growth in Nigeria Journal of Social Science, 2(2), 19-24.

World Development Report. (2008). Agriculture for Development. Washington D.C: WBP.

World Bank. (2013). World Bank Development Indicators 2013. Washington D.C: WorldBank.

Zirra, C. T. O., and Ezie, O. (2017). Government Fiscal Policy and Agricultural Sector Output in

Nigeria: Evidence from Fully Modified Ordinary Least Square (FMOLS). Journal of Research in Business, Economics and Management, 8(3), 1434-1443.

Zhattau, P.(2013). Fiscal Policy as an Engine of Economic Growth in Nigeria. International Journal of Arts and Humanities, 2(2),282-298 